\title{
Retribution in the Wisdom Tradition and Literature
}

\author{
Chandra Gunawan
}

Email: cgunawan@tukampen.nl

\begin{abstract}
Even though the question of retribution seems to interconnect the texts that comprise the bible's wisdom literature, many scholars are reluctant to recognize the reality of any type of harmony among them. In fact, some researchers see these texts' perspectives on retribution as being so incompatible that they would argue that they are contradictory. Given this, one is left to wonder about how to make sense of the tension among these books when they address the issue of retribution in the OT, how to comprehend its meaning in the wisdom traditions, and how to compare it to other OT traditions.
\end{abstract}

Key words: retribution, Justice, wisdom literature, wisdom tradition

Walaupun pertanyaan mengenai keadilan nampaknya mampu menghubungkan teks-teks dalam literatur sastra hikmat dalam Alkitab, banyak ahli yang ragu-ragu untuk menerima realitas adanya kesatuan diantara tulisan-tulisan sastra hikmat. Bahkan, beberapa peneliti melihat berbagai pandangan dalam teks-teks hikmat sebagai pemikiran yang tidak harmonis bahkan bertentangan. Jika demikian, kita patut memikirkan bagaimana menyelaraskan berbagai ketegangan pemikiran dalam tulisan-tulisan tersebut ketika buku-buku tersebut membahas konsep mengenai keadilan/pembalasan dalam literatur hikmat dan memahami arti dan makna dari konsep tersebut dalam literatur hikmat dan maknanya dalam literatur PL lainnya.

Kata-kata kunci: Pembalasan, Keadilan, Sastra Hikmat, Tradisi Hikmat 
Wisdom is universal. It is known not only in the Christian tradition but also in other traditions. For example, a Chinese proverb says, "It is easy to find a thousand soldiers but hard to find a good [wise] general"; it emphasizes that a leader's wisdom is more valuable and important than the strength of a thousand powerful men.

What is wisdom? Bartholomew and O'Dowd consider wisdom to be "about how all ... activities [speaking, working, etc.] find their meaning in the whole of God's created order." ${ }^{\prime 1}$ Since wisdom tradition has ability both to adopt other traditions and to preserve her own tradition, it forms a new tradition with distinctive characters, develops pedagogy from experiences, and interprets real-life situations from the perspective of God (cf. Prv. 1.7). ${ }^{2}$ This tradition is called the wisdom tradition, ${ }^{3}$ and the Old Testament passages that preserve this tradition are identified as wisdom literature. ${ }^{4}$

The concept of retribution is important in wisdom literature and is arguably a unifying theme throughout the literature. Although Qoheleth and the books of Proverb and Job the concept, their perspectives on it are incongruous; in reality, their viewpoints on retribution seem contradictory. While the book of Proverb emphasizes the notion of retribution, the books of Job and Qoheleth seem to argue against it. This essay will discuss how to understand the tension between these texts when they touch on the idea of retribution. To answer the question, firstly, this essay will expound upon the concept of retribution in the OT; second, will analyze the wisdom literature's diverse perspectives on retribution; and, lastly, will contrast how the concept is understood in the wisdom tradition with other OT traditions.

\footnotetext{
${ }^{1}$ C.G. Bartholomew and R.P. O'Dowd, Old Testament Wisdom Literature: A Theological Introduction (Downers Grove: IVP, 2011), 24,28-30.

${ }^{2}$ Gerhard Von Rad is considered to be an important scholar who succeeds in showing that the wisdom tradition is another perspective/tradition in the Old Testament; see B.S. Childs, Biblical Theology of the Old and New Testaments: Theological Reflection on the Christian Bible (Minneapolis: Fortress, 1992), 189,190. A text that is a part of the wisdom tradition has four characteristics: (i) "it begins with the 'fear of Yahweh"', (ii) "it is concerned with the general order and pattern of living in God's creation," (iii) it provides discernment for the particular order and circumstances of our lives," (iv) "it is grounded in tradition" (See Bartholomew and O'Dowd, Old Testament Wisdom, 24-30.). According to Clements the wisdom tradition developed in three phases: (i) when it was used as folk wisdom, (ii) when it was used in the royal court, and (iii) when it was compiled into a collection of books in the post-exilic period. R.E. Clements, Wisdom in Theology (Carlisle: Paternoster, 1992), 24-30.

${ }^{3}$ Cf. Bartholomew and O'Dowd, Old Testament Wisdom, 22-24; M. Sneed, ed., Was There a Wisdom Tradition? New Prospects in Israelite Wisdom Studies, SBLAIL 23 (Atlanta: SBL, 2015), pt. 1. Scholars debate about how to distinguish between "wisdom and other genres." Since the wisdom tradition is present in the wisdom literature and in other OT texts, in my opinion, it is better to identify it as the collective book that preserves the wisdom tradition, as a genre, or as a way to understand life. For a helpful discussion regarding the nature of wisdom in biblical and classical traditions, see M.C. Legaspi, Wisdom in Classical and Biblical Traditions (Oxford: Oxford University Press, 2018). Legaspi argues that, although wisdom traditions are diverse, they have commonalities, namely, their concern to understand the world and their focus on the human integrity.

"The discussion on Wisdom Literature could be seen in R.J. Clifford, "Introduction to Wisdom Literature," in The New Interpreters' Dictionary of the Bible Vol 5: S-Z, ed. K.D. Sakenfeld (Nashville: Abingdon, 1997), 1-2.
} 


\section{Perspectives on Retribution}

Walton defines retribution as "the conviction that the righteous will prosper and the wicked will suffer, both in proportion to their respective righteousness and wickedness." ${ }^{5}$ Although the concept of retribution is not particularly well-preserved in Israelite tradition, Walton shows that it was pervasive throughout the ancient Near East. ${ }^{6}$ While the logic used to understand retribution within Israelite tradition is different from that of its milieu, the existence of the concept indicates that it was a significant part of how ancient people viewed the world. Nonetheless, how the ancients described the concept varied widely, and there is a variety of opinions about it even within the Old Testament itself. Thus, we will explore a few ways to interpret this plurality of ideas concerning it.

\section{Retribution as Principle}

Walton maintains that retribution in the Old Testament is seen as a principle. ${ }^{7}$ The fundament of this principle is God's commitment to justice; on the other hand, the Israelite belief in ethical monotheism carried with it the assumption that, one, evil is under God's control and, two, that God has the absolute ability to exact justice. ${ }^{8}$

Nevertheless, whether or not "retribution" can be identified as a principle is arguable. Although the concept of retribution is important in the wisdom literature and other Old Testament books (such as in the prophetic books), it is not as prominent as other OT themes like "history of redemption" and "covenant." Therefore, it is more reasonable to identify the concept of retribution as a great theme in the Old Testament rather than as a principle. ${ }^{9}$

\footnotetext{
${ }^{5}$ J.H. Walton, "Retribution," in Wisdom, Poetry, and Writings, ed. T. Longman III and P. Enns, DOT (Downers Grove: IVP, 2008), 647. Also see R. Murphy, Wisdom Literature: Job, Proverbs, Ruth, Canticles, Ecclesiastes, Esther, FOTL, XIII (Grand Rapids: Eerdmans, 1981), chap. 1. The name wisdom literature is widely used to call the books of Proverbs, Job, Ecclesiastes, and some apocryphal writings.

${ }^{6}$ Walton, "Retribution," 647-49. See also Murphy, Wisdom Literature: Job, Proverbs, Ruth, Canticles, Ecclesiastes, Esther, 9-12.

${ }^{7}$ Walton, "Retribution," 647.

${ }^{8}$ A. Laato and J.C. De Moor, "Introduction," in Theodicy in the World of the Bible (Leiden: Brill, 2003), xx; R.J. Vannoy, "The Theology of Retribution," in Dictionary of Old Testament Theology and Exegesis 4, ed. W.A. Van Gemeren (Carlisle: Paternoster, 1996), 1140; Walton, "Retribution," 650. Walton maintains that in addition to monotheism, the Israelite tradition was heavily influenced by the absence of the belief in post-death divine judgement, by which one would receive rewards or punishment for how he or she lived while alive. However, Walton's supposition here is an argument from silence because it assumes that the Israelites did not believe in a post-death judgment instead of proving that they did not. Moreover, his claim is not even completely true because in Ps. 49.5-15 and Dan 12.2 there is mention of a reward or punishment that one may receive in the "eschaton."

${ }^{9}$ A great theme in the biblical texts refers to a topic that connects these writings, such as the theme of covenant. The principle in biblical text appoint at cardinal teaching in the bible, for instance, monotheism. While the principle does not always connect all writings, it becomes a basis for God's people belief and lives.
} 
Retribution as Logic of Justice

Given that ancient Near Eastern people did not hold their gods responsible for human suffering, they did not face philosophical issues when it came to reconciling their belief in their gods with the reality of injustice/suffering. ${ }^{10}$ In contrast, the Israelite tradition had a different belief system, one that held that God is just and will act in accord with his justice. Moreover, they maintained that God is the only God and that there is no other power (including evil) equal to the God of Israel. consequently, they faced a substantial level of cognitive dissonance whenever injustice seemed to prevail. ${ }^{11}$ Therefore, theodicy was developed to logically reconcile the experience of injustice with the belief in an omnipotent, just God.

How did the Israelite tradition deal with this issue? There are different approaches used to understand this issue, and one of them is "retribution theodicy." ${ }^{12}$ In this approach, to grasp the notion of theodicy, retribution is seen as the logical outcome of sinful behavior. In other words, people who held this view believed that human suffering stems from unrepentant $\sin$. The existence of this perspective could be seen in the theological perspective of Job's friends. ${ }^{13}$ According to Laato \& De Moor, the retribution theodicy could be found in many texts of the OT such as in Deuteronomy, Leviticus, Ezra, Nehemiah, Hosea, Jeremiah, and Proverbs. ${ }^{14}$ On the other hand, they also believe that the "retribution theodicy" expanded due to a national crisis (such as the exile) and under the influence of the deuteronomistic tradition (the covenant theology).

It is debatable whether or not the OT concept of retribution, particularly that of the wisdom literature, was employed to address the problem of theodicy. Even in the book of Job, in which theodicy is probably the main issue, the concept of retribution was not used to answer the issue. Largely, the question of why the righteous suffer is not definitively addressed.

\footnotetext{
${ }^{10}$ Laato and De Moor, "Introduction," xxx-xxxviii. Laato \& De Moor show that ancient Near Eastern culture influenced Israelite theodicy, particularly their understanding of retribution. The Mesopotamian law documents and Egyptian sages believed that punishment and suffering are caused by disobedience or evil deeds; this worldview and together with the deuteronomistic tradition of "curse and blessing" form the concept of retribution theodicy in Israelite tradition. In my opinion, it is arguable whether or not Mesopotamian law and Egyptian sages could be used as a lens for understanding the Israelite theodicy since the Israelite wisdom tradition and ancient Near Eastern wisdom are noticeably distinct. In addition, it would be reductionist to understand covenant theology only in the light of "curse and blessing."

${ }^{11}$ Walton, "Retribution," 647,650.

12 Laato and De Moor, "Introduction," xxx-liv.

13 J.L. Crenshaw, Old Testament Wisdom (London: SCM, 1981), 118-19.

${ }^{14}$ Laato and De Moor, "Introduction," xxxii-xxxiii. See also L. Boström, "Retribution and Wisdom Literature," in Exploring Old Testament Wisdom: Literature and Themes, ed. D.G. Firth and L. Wilson (Downers Grove: IVP, 2016), chap. 7.
} 


\section{Retribution as Theology}

In this approach, retribution is not understood as a logic of justice but as a theology. ${ }^{15}$ As a theology, retribution was discussed primarily to understand God rather than human suffering. There are two ways to see retribution in this mode of thinking: as a mystery or as a part of God's revelatory action.

The premise that retribution is a mystery aspect of reality assumes that it is a phenomenon that transcends human understanding. Moreover, it is a reality that affects one's present existence as well as one's afterlife. ${ }^{16}$ From this perspective, God's people are required to have faith in God rather than to question God's mysterious work. This viewpoint on retribution can be seen in all the books of the wisdom literature (particularly in the book of Job and Qoheleth). ${ }^{17}$ Conversely, the retribution can also be understood as God's revelatory action. ${ }^{18}$ In other words, God sometimes allows the righteous to suffer or the wicked to appear to prosper. This appearance of injustice does not happen because God fails to execute his justice. Instead, it happens because he has a particular purpose for his people. This attitude towards retribution seems more reasonable and should be the lens through which the concept is analyzed in the wisdom tradition and its resultant literature.

\section{The Theology of Retribution in Wisdom Tradition and Literature}

The idea of retribution is present in the wisdom tradition and also other traditions such as deuteronomic tradition (cf. Deut.28-29). On the other hand, this idea is also present in some poetic books such as the Psalms. In this section, we will firstly discuss the idea of retribution in the wisdom literature (Job, Proverbs, and Qoheleth), ${ }^{19}$ and then we will briefly explore how this idea is handled in the Psalms and the prophetic tradition so that we can have a broader understanding of how the theology of retribution is understood in the wisdom literature, as well as how it relates to the other OT traditions. ${ }^{20}$

\footnotetext{
15 Walton, "Retribution," 649. Concerning the concept of God in wisdom traditions, see J.L. Crenshaw, "The Concept of God in Old Testament Wisdom," in In Search of Wisdom: Essays in Memory of John G. Gammie, ed. L.G. Perdue, B.B. Scott, and W.J. Wiseman (Louisville: WJK, 1993), 1-18.

${ }^{16}$ Walton, "Retribution," 650.

${ }^{17}$ Walton, 650. Walton demonstrates that although this approach is present in the Christian tradition, it was not a part of the pre-Christian Israelite tradition. Although most scholars agree with Walton's conclusion, this bases on the argument from silence.

18 Walton, 650.

${ }^{19}$ R.N. Whybray, The Intellectual Tradition in the Old Testament (Berlin: De Gruyter, 1974), 31,43,54,69. Whybray $(1974: 31,43,54,69)$ discusses "The Intellectual Tradition in the Old Testament," and he concludes that although a "wise man" was a person with extraordinary literary ability, by which he could write timeless books like Proverbs, Job and Qoheleth, such a man was most likely not a professional teacher, advisor, or author.

${ }^{20}$ Although retribution is the main theme in the wisdom tradition and is also present in the prophetic tradition, the preeminence of covenant, the main theme of the latter, is not present in the former. For further discussion
} 
Retribution in the Wisdom Literature

According to Walton, the way retribution is thought of is not uniform. In fact, the wisdom tradition sees it from a theological vantage point, and sometimes it is used as a logical premise to address the problem of theodicy. ${ }^{21}$ Additionally, although it is debatable whether the book of Job was written to address the issue of theodicy, it is the only text in which this issue seems to be present. Therefore, it is reasonable that we will focus our observation primarily on retribution and not on theodicy, which is only sparsely present in the wisdom literature. In the book of Proverbs, retribution is clearly seen and is formulated in the sequential character $\rightarrow$ conduct $\rightarrow$ consequence. ${ }^{22}$ Some sayings follow this model (such as in Prov. 13.22, 25, 14.14). Despite this, van Leeuwen shows that there is also a theological exception in the book of Proverbs in which it is shown that the righteous should endure suffering, but since God is just, they are still better off than the wicked, whose prosperity will be taken away in the end (cf. Prv. 24.20, 28.20). ${ }^{23}$ Therefore, it will be reductionist if the theology of retribution in the book of Proverb is only seen as a deed-consequence process/system. ${ }^{24}$

The theology of retribution also has an important role in the book of Job. ${ }^{25}$ In this book, the theology of retribution collides with the issue of theodicy. Crenshaw believes that Job's spiritual crisis represents "a decisive stage in Israel's dealing with God [in which] ... divine justice threatened to collapse because of the burdens placed upon it by historical events." 26 The concept of mechanical retribution is preserved in the belief of Job's friends (such as in Job 4.7-9, 8.8-13, 10.13-20); they believe that justice is the greatest principle and that even God is under this principle. ${ }^{27}$ Nonetheless, Job, who symbolizes Israel in this story, protests against this perspective (such as in Job 9.15-22). ${ }^{28}$ Despite this, Job's question is not definitively

see J.A. Grant, "Wisdom and Covenant," in Wisdom, Poetry, and Writings, ed. T. Longman III and P. Enns, DOT (Downers Grove: IVP, 2008), 858-63.

${ }^{21}$ Walton, "Retribution," 649.

${ }^{22}$ B.K. Waltke, The Book of Proverb Chapters 1-15 (Grand Rapids: Eerdmans, 2004), 73. Klaus Koch made a significant contribution to this discussion by describing the concept of retribution in the book of Proverbs as a mechanical, impersonal system. Further discussion on this issue, see P.D. Miller, Sin and Judgment in the Prophets (Chico: Scholars, 1982), 132-34.

${ }^{23}$ R.C. Van Leeuwen, "Wealth and Poverty," Hebrew Studies 33 (1992): 34. According to van Leeuwen, the existence of futuristic hope in the book of Proverbs is difficult to understand since in the Old Testament this kind of hope was rare; therefore, he argues that the book of Proverb seems to maintain the "Yahwistic faith."

${ }^{24}$ Boström, "Retribution and Wisdom Literature," chap. 7.

${ }^{25}$ J.H. Walton, "Job," in Wisdom, Poetry, and Writings, ed. T. Longman III and P. Enns, DOT (Downers Grove: IVP, 2008), 340. Walton shows that the dialogue in Job takes a setting like a court in which there are three claims that are discussed i.e., (i) "God is just;" (ii) "Job is righteous;" (iii) "the retribution principle is true."

${ }^{26}$ Crenshaw, Old Testament Wisdom, 116.

${ }^{27}$ Crenshaw, 118-19.

${ }^{28} \mathrm{~W}$. Brueggemann, Theology of the Old Testament (Minneapolis: Fortress, 1997), 388-89. According to Brueggemann, Israel, through Job's words, argues against Yahweh and asserts that "Yahweh violates Yahweh's own command ... Yahweh is unreliable and morally indifferent." 
answered, nor are his friends justified. Moreover, the answer to the question of why God allows the righteous to suffer injustice is left as a mystery (cf. Goldingay 2006:590). ${ }^{29}$ Therefore, Walton is correct in that the purpose of "the book of Job is to perform the radical surgery that separates theology and theodicy, contending that in the end Yahweh's justice must be taken on faith rather than worked out philosophically." 30

In the book of Qoheleth the author sees that retribution is not working (such as in Qoh. 9.1-2). Perdue (1994:239) assumes that in the book "there was ... a deep-seated erosion of confidence in the providence of God. One problem is the retreat of the creator into the impenetrable darkness of the heavenly regions." ${ }^{31}$ The problem worsens when God seems to ignore the injustice happening on earth and abandons his "retribution principle." 32 For this reason, Qoheleth was pessimistic, thinking that not even wisdom was enough to make the cosmos a better place (such as in Qoh.1.13-14) (cf. Perdue 1994:239-240). ${ }^{33}$ Nevertheless, this does not mean that Qoheleth did not trust in God. In actuality, he emphasizes that God is sovereign and that he rules over the cosmos and humanity (Qoh. 11.9). ${ }^{34}$ Whybray thinks that Qoheleth stresses that God will not distinguish the righteous and the wicked, but God also will reward man based on what is deserved. ${ }^{35}$ This theological tension was not solved by Qoheleth. In other words, rather than questioning God's justice, Qoheleth teaches the retribution as a mystery.

Brueggemann uses a court as a model to understand different voices and tensions in the Old Testament. ${ }^{36}$ According to Brueggemann the core testimony in the OT tradition is "Yahweh's faithful sovereignty and Yahweh's sovereign fidelity." On the other hand, there is a counter-testimony from Israel that emphasizes "Yahweh's hiddenness, ambiguity, and negativity." In Brueggemann's opinion, the theology of retribution in the book of Proverbs could be seen as a part of the counter-testimony in which the emphasis on "Yahweh's hiddenness" is maintained (pp. 336, 338, 346-347, 348-351). Consequently, he asserts that the book of Proverb does not emphasize a deed-consequence teaching but emphasizes the "the hidden, final, free governance of Yahweh." However, the theology of retribution in the books of Job and Qoheleth, in Brueggemann's theological framework, is seen as the counter-

\footnotetext{
${ }^{29}$ J. Goldingay, Old Testament Theology 2: Israel's Faith (Downers Grove: IVP, 2006), 590.

${ }^{30}$ Walton, “Job," 649.

${ }^{31}$ L. Perdue, Wisdom \& Creation: The Theology of Wisdom Literature (Nashville: Abingdon, 1994), 239.

32 R.N. Whybray, Ecclesiastes, OTG (Sheffield: Sheffield Academic, 1989), 73-75.

${ }^{33}$ Perdue, Wisdom, 239-40.

${ }^{34}$ Whybray, Ecclesiastes, 74. Whybray suggests that Qoheleth is unsure about God's level of control over the cosmos. From Qoheleth's perspective, while retribution sometimes seems to be an impersonal supernatural phenomenon, at other times, it appears to be an act of God's justice.

35 Whybray, 76.

${ }^{36}$ Brueggemann, Theology of the Old Testament, 318-319,400-401.
} 
testimony, which emphasizes the negative perspective and maintains questions on God's retributive works. ${ }^{37}$

Goldingay examines the theology of retribution under the theme "How Life Works," and he shows that life works mysteriously. ${ }^{38}$ He shows that the theology of retribution is present in the wisdom literature and Old Testament, and it is clear that God works through retribution. ${ }^{39}$ However, even though the suffering faced by God's people could be seen as correction or testing, Goldingay illustrates that retribution does not always happen and that the reason behind the "failure of the principle of retribution" is also uncertain. ${ }^{40}$ Similar to Brueggemann, Goldingay sees that the theology of retribution is a point of tension in wisdom literature, but unlike Brueggemann, he interprets the tension as a mystery, not as a countertestimony.

In my opinion, there is another way to sift through the plurality of theological perspectives on retribution within the books of Proverbs, Job and Qoheleth. It is possible that the three books were written and collected to argue against those who misunderstand the retributive principle. ${ }^{41}$ The concept of retribution that is attacked in the books of Job and Qoheleth is not synonymous with the theology of retribution that is taught in the book of Proverbs. Put differently, the concept of retribution that is attacked by Job and Qoheleth is a kind of "mechanical retribution," which is, as clearly shown by van Leeuwen, different from the retributive concept that is taught in Proverbs. As a matter of fact, the book of Proverb appears to teach the correct concept of retribution in which retribution is seen as a dynamic work of God. In short, the three books highlight the same teaching (teaching of retribution), although they have different perspectives and speak from different contexts. The book of Job sees the retribution from the perspective and the context of suffering. The book of Proverb views the theme from the standpoint of education. The book of Qoheleth was written from the perspective of philosophy.

\footnotetext{
${ }^{37}$ Brueggemann, 393-96. Brueggemann posits that the counter-testimony that is articulated in the book of Job is passionate and persuasive while the book of Qohelth is direct and unpersuasive. On the other hand, both believe that although God is the source of human life and he is sovereign and will judge men, but his work and judgment do not depend on external conditions.

${ }^{38}$ Goldingay, Old Testament Theology 2: Israel's Faith, 596-631.

${ }^{39}$ Goldingay, 610. Concerning the concept of retribution in Psalms, see P.J. Botha, "Psalm 39 and Its Place in the Development of a Dictrine of Retribution in the Hebrew Bible," Old Testament Essays 30, no. 2 (2017): $240-64$. ${ }^{40}$ Goldingay, Old Testament Theology 2: Israel's Faith, 615-31.

${ }^{41} \mathrm{~T}$. Longman III, Proverbs, BCOT (Grand Rapids: Baker, 2006), 61-63. Longman III postulates that Proverbs, Job and Qoheleth teach on the retributive concept in an interconnected way, namely, Job and Qoheleth attempt to correct any misunderstanding about it resulting from a reading of Proverbs. In my opinion, although this approach seems to harmonize how it is taught among the three, it assumes that the wisdom literature has gone through a process or redaction, and there is insufficient evidence to suppose that this is true.
} 


\title{
3. Retribution in Psalms and the Prophetic Tradition
}

In the book of Psalms, the theology of retribution is used as the theological basis for addressing the existential reality of suffering and injustice. Unlike the aforementioned books, the psalmists seek retribution, although they never question God's justice. In effect, as in the wisdom literature, retribution becomes the reason for the psalmist's putting his faith in God. Firth observes the perspective(s) of the Psalms on the issue of violence and its relation to the concept of retribution and stresses: ${ }^{42}$

\begin{abstract}
"Although all the psalms examined reflected a consistent position of violence that was currently suffered and in which retribution was sought, in no case did the psalmist seek approval for the enactment of personal retribution ... [based on Ps. 27.6] [psalmist believes that] there is no need to seek [personal] retribution because the world view of the psalm ... assumes that Yahweh acts on the behalf of the righteous against the wicked."
\end{abstract}

The theology of retribution also becomes the main message in the prophets in which disobedience and unfaithfulness to Yahweh lead to Israel's suffering (as a consequence) in the form of a punishment. ${ }^{43}$ Miller is correct in that being punished, according to the prophetic traditions, is not only a matter of deed and its consequence. Although a punishment could be the result of God acting judiciously, it could also serve as a means for purifying his people. ${ }^{44}$ Nevertheless, the family metaphor used in the prophetic traditions, such as God as the merciful father (Isa. 63.16, Jer. 3.19) and the faithful husband (Isa. 54.5; Jer. 31.32), highlights another side of the covenant: love, mercy, and forgiveness. Furthermore, in the book of Jonah a strict interpretation of retribution seems to collapse since God chooses to forgive Nineveh, a sinful nation, rather than punishing them according to their sinful deeds (Jon. 4.11). Thus, as is the case in the wisdom literature, God is not subject to the "system of retribution" but transcends it. Thus, the wisdom tradition, psalms, and prophetic traditions are harmonious.

\section{Conclusion}

The wisdom tradition grows and develops in the real-life situation, specifically the context of suffering. The wisdom teaching about retribution was applied primarily as a theology rather than as a logic of justice or a system of justice. The theology of retribution, particularly the way it is conveyed in Job, leads God's people to put their faith in God who is

\footnotetext{
42 D.G. Firth, Surrendering Retribution in the Psalms, PBM (Milton Keynes: Paternoster, 2005), 141-42.

${ }^{43}$ Miller, Sin and Judgment in the Prophets, 134-37.

${ }^{44}$ Miller, 137.
} 
just and not to question his justice. For this reason, the wisdom tradition begins its searching on wisdom from fear/reverence of the Lord (Prov. 1.7). ${ }^{45}$ Goldingay is correct that wisdom could not answer every question about human life and God; therefore, the human-God relationship is important, and this relationship should direct God's people to trust, submit and learn to live with mystery. ${ }^{46}$

There are a few ways to unpack the plurality of OT teachings on retribution. For example, Brueggemann understands this as a counter-testimony, Van Leeuwen sees it as a contradiction, and Goldingay interprets it as a mystery. However, one could also harmonize the varying OT viewpoints on retribution. While the book of Proverb becomes the "grammar" of the wisdom literature, the traditions behind the books of Job and Qoheleth interpreted and applied the rich concept of God's justice to real life and human experience. ${ }^{47}$

Nevertheless, our discussion leads to another important issue. In thinking about the importance of retribution in the OT, one may also wonder about how it relates to salvation. More clearly, how does retribution theology inform researchers' understanding of justification theology in the Old Testament? Given the fact that God's retribution seems, at least on the surface, inconsistent at times, how should the concept of salvation in the OT be understood? Moreover, how should OT soteriology be formulated in light of the theology of retribution?

The reformed perspective emphasizes the limitation of human knowledge in understanding God. As a matter of fact, Frame (2013:703) says, "One reason God is incomprehensible is that he has chosen not to reveal to us everything about himself ... God is incomprehensible not only in what is unrevealed but also in his revelation." This approach and understanding are important and are in accord with the wisdom tradition. Rather than trying to use logic and philosophy to unravel the mystery of God's acts, it is better for us, with Romans 11.33-36 in mind, to focus on putting our faith in and glorifying him.

\footnotetext{
${ }^{45}$ Goldingay, Old Testament Theology 2: Israel's Faith, 581,592,596. Goldingay interprets the phrase "yir'at yhwh" as an attitude (not a feeling) that leads man to acknowledge, to submit to and to obey Yahweh. Hence, the reverence of the Lord becomes the center of wisdom for at least two reasons: humility and faith. In order for human beings to revere God, they must first possess the humility to recognize the limitations of human understanding and, second, have faith in the omniscience of God to lead them down wise paths. Put differently, wisdom does not entail the ability to answer existential questions but the willingness to live with a significant level of ontological mystery.

${ }^{46}$ Goldingay, 576.

${ }^{47}$ It is also possible to understand the three books of wisdom literature in the context of progressive revelation in which an earlier book sets the stage for a later book.
} 


\section{Bibliography}

Bartholomew, C.G., and R.P. O'Dowd. Old Testament Wisdom Literature: A Theological Introduction. Downers Grove: IVP, 2011.

Boström, L. "Retribution and Wisdom Literature." In Exploring Old Testament Wisdom: Literature and Themes, edited by D.G. Firth and L. Wilson. Downers Grove: IVP, 2016.

Botha, P.J. "Psalm 39 and Its Place in the Development of a Dictrine of Retribution in the Hebrew Bible." Old Testament Essays 30, no. 2 (2017): 240-64.

Brueggemann, W. Theology of the Old Testament. Minneapolis: Fortress, 1997.

Childs, B.S. Biblical Theology of the Old and New Testaments: Theological Reflection on the Christian Bible. Minneapolis: Fortress, 1992.

Clements, R.E. Wisdom in Theology. Carlisle: Paternoster, 1992.

Clifford, R.J. "Introduction to Wisdom Literature." In The New Interpreters' Dictionary of the Bible Vol 5: S-Z, edited by K.D. Sakenfeld. Nashville: Abingdon, 1997.

Crenshaw, J.L. Old Testament Wisdom. London: SCM, 1981.

- - - "The Concept of God in Old Testament Wisdom." In In Search of Wisdom: Essays in Memory of John G. Gammie, edited by L.G. Perdue, B.B. Scott, and W.J. Wiseman, 118. Louisville: WJK, 1993.

Firth, D.G. Surrendering Retribution in the Psalms. PBM. Milton Keynes: Paternoster, 2005.

Goldingay, J. Old Testament Theology 2: Israel's Faith. Downers Grove: IVP, 2006.

Grant, J.A. "Wisdom and Covenant." In Wisdom, Poetry, and Writings, edited by T. Longman III and P. Enns, 858-63. DOT. Downers Grove: IVP, 2008.

Laato, A., and J.C. De Moor. "Introduction." In Theodicy in the World of the Bible. Leiden: Brill, 2003.

Legaspi, M.C. Wisdom in Classical and Biblical Traditions. Oxford: Oxford University Press, 2018.

Longman III, T. Proverbs. BCOT. Grand Rapids: Baker, 2006.

Miller, P.D. Sin and Judgment in the Prophets. Chico: Scholars, 1982.

Murphy, R. Wisdom Literature: Job, Proverbs, Ruth, Canticles, Ecclesiastes, Esther. FOTL, XIII. Grand Rapids: Eerdmans, 1981.

Perdue, L. Wisdom \& Creation: The Theology of Wisdom Literature. Nashville: Abingdon, 1994.

Sneed, M., ed. Was There a Wisdom Tradition? New Prospects in Israelite Wisdom Studies. SBLAIL 23. Atlanta: SBL, 2015.

Van Leeuwen, R.C. "Wealth and Poverty." Hebrew Studies 33 (1992): 25-35.

Vannoy, R.J. "The Theology of Retribution." In Dictionary of Old Testament Theology and Exegesis 4, edited by W.A. Van Gemeren, 1140-49. Carlisle: Paternoster, 1996.

Waltke, B.K. The Book of Proverb Chapters 1-15. Grand Rapids: Eerdmans, 2004.

Walton, J.H. "Job." In Wisdom, Poetry, and Writings, edited by T. Longman III and P. Enns, 333-46. DOT. Downers Grove: IVP, 2008.

- - - "Retribution." In Wisdom, Poetry, and Writings, edited by T. Longman III and P. Enns, 647-55. DOT. Downers Grove: IVP, 2008.

Whybray, R.N. Ecclesiastes. OTG. Sheffield: Sheffield Academic, 1989.

- - . The Intellectual Tradition in the Old Testament. Berlin: De Gruyter, 1974. 